\title{
About the specific status of Baiomys musculus and B. brunneus
}

\author{
Giovani Hernández-Canchola ${ }^{1}$, and Livia León-Paniagua ${ }^{2 *}$ \\ ${ }^{1}$ Museum of Natural Science, Louisiana State University, Baton Rouge 70803, Louisiana, USA. Email: canchola@lsu.edu (GHC). \\ ${ }^{2}$ Colección de Mamíferos - Museo de Zoología "Alfonso L. Herrera", Departamento de Biología Evolutiva, Facultad de Ciencias, \\ Universidad Nacional Autónoma de México, CP. 04510. Ciudad de México, México. Email: llp@ciencias.unam.mx (LLP). \\ *Corresponding author
}

\begin{abstract}
The southern pygmy mouse, Baiomys musculus, is distributed in arid and semiarid lowlands, from southern Nayarit and central Veracruz in México to northwestern Nicaragua, excluding the Yucatán Peninsula and the Caribbean tropical lowlands. Previous reports suggest that $B$. musculus includes two clades that may be eligible for specific status, although this remains uncertain. We used mitochondrial DNA (cytochrome b) and morphometric data to test whether two lineages exist within the species. Molecular data support the existence of two monophyletic groups with genetic distances of 6.69 \% between them: clade I, a western clade found in Colima, Jalisco, and Michoacán; and clade II, an eastern clade found in Guerrero, Morelos, Oaxaca, and Veracruz. Morphologically, clade I individuals are larger than clade II. Moreover, these clades seem to be allopatric, and their geographic boundaries are located in the complex topography of western México. Examination of previous reviews in addition to the data from this study suggest that it may be appropriate to recognize each clade as a species: clade I as $B$. musculus (Merriam, 1892) and clade II as B. brunneus (Allen and Chapman, 1897). Future studies with nuclear or genomic data, including Central American populations, would verify this taxonomic hypothesis.
\end{abstract}

El ratón pigmeo del sur, Baiomys musculus, se distribuye en las tierras bajas áridas y semiáridas, desde el sur de Nayarit y el centro de Veracruz en México, hasta el noroeste de Nicaragua, excluyendo la península de Yucatán y las tierras bajas tropicales del Caribe. Previamente fue reportado que existen dos clados genéticos que podrían representar especies diferentes, aunque esto sigue siendo incierto. Utilizamos DNA mitocondrial (citocromo b) y datos morfométricos para analizar la existencia de dos linajes al interior de la especie. Los datos moleculares confirman la existencia de dos grupos monofiléticos con distancias genéticas entre ellos de $6.69 \%$ : el clado l, o el clado del oeste que se distribuye en Colima, Jalisco y Michoacán; y el clado II, o clado del este que habita en Guerrero, Morelos, Oaxaca y Veracruz. Los análisis morfométricos mostraron que los individuos del clado I son más grandes que los del clado Il. Además, estos clados parecen ser alopátricos, y sus límites geográficos se localizan en la compleja topografía del oeste de México. Después de integrar previas investigaciones con nuestros datos, sugerimos apropiado renombrar al clado I como B. musculus (Merriam, 1892), y al clado Il como B. brunneus (Allen and Chapman, 1897). Es necesario realizar estudios con datos nucleares o genómicos, incluyendo a las poblaciones de Centro América, para poder validar esta hipótesis taxonómica.

Keywords: Mitochondrial DNA; morphometric data; southern pygmy mouse; taxonomic change; western México.

(c) 2021 Asociación Mexicana de Mastozoología, www.mastozoologiamexicana.org

\section{Introduction}

The mice in the genus Baiomys belong to the cricetid tribe Baiomyini (Pardiñas et al. 2017) and includes some of the smallest North American rodents in the subfamily Neotominae, commonly known as pygmy mice (Packard 1960). Baiomys comprises two extant species: the northern pygmy mouse (B. taylori) and the southern pygmy mouse (B. musculus; Packard 1960; Pardiñas et al. 2017). The southern pygmy mouse primarily inhabits arid and semiarid lowlands (Packard and Montgomery 1978), from southern Nayarit and central Veracruz in México to northwestern Nicaragua, excluding the Yucatán Peninsula and the Caribbean tropical lowlands (Packard and Montgomery 1978; Pardiñas et al. 2017). This distribution overlaps with B. taylori in the west-central Mexican states of Colima, Jalisco, Michoacán, and Nayarit (Pardiñas et al. 2017). In this sympatric area, B. musculus and B. taylori are more strongly morphologically differentiated from each other than are other allopatric populations of each species (Packard 1960).
Baiomys musculus originally was described as Sitomys musculus (Merriam, 1892), and later the subgenus Baiomys was defined based on morphological differences (True 1894). Baiomys was recognized as an independent genus by Mearns (1907), who also was the first to use the binomial Baiomys musculus. Two years later, Baiomys was considered a subgenus of Peromyscus (Osgood 1909), but Miller (1912) subsequently re-recognized it as an independent genus. Currently, eight subspecies are recognized within B. musculus: B. m. musculus (Merriam, 1892; type specimen from Colima, México); B. m. brunneus (Allen and Chapman, 1897; type specimen from Veracruz, México); B. m. nigrescens (Osgood, 1904; type specimen from Chiapas, México); B. m. grisescens Goldman, 1932 (type specimen from Tegucigalpa, Honduras); B. m. infernatis Hooper, 1952 (type specimen from Oaxaca, México); B. m. pallidus Russell, 1952 (type specimen from Morelos, México); B. m. handleyi Packard, 1958 (type specimen from El Quiche, Guatemala); and B. m. pullus Packard, 1958 (type specimen from Esteli, Nicaragua; Figure 1). 
Baiomys musculus mice have been studied from different perspectives, including assessment of morphometry (Osgood 1909; Hooper 1952; Packard 1960), karyotypes (Lee and Elder 1977), allozymes (Calhoun et al. 1989), demographic features and habitat preferences (García-Estrada et al. 2002; Schnell et al. 2008), geometric morphometrics (Abuzeineh 2006), singing behavior (Miller and Engstrom 2007), intra-specific niche modeling (Martínez-Gordillo et al. 2010), landscape genetics (Vargas et al. 2012), and ecotoxicology (Galván-Ramírez 2020). With respect to taxonomic relationships, analysis of the mitochondrial gene cytochrome b (CytB), detected two clades within B. musculus, one located in the Mexican states of Jalisco and Michoacán, and the other in Chiapas, Guerrero, Oaxaca, and Puebla (Amman and Bradley 2004). The genetic divergence between these two clades (genetic $p$-distance $=6.46 \%$ ) suggests that both units may be eligible for species status (Amman and Bradley 2004), however, the eight subspecies are still recognized (Pardiñas et al. 2017).

Our objective was to revisit the taxonomic status of these two monophyletic groups within B. musculus using additional genetic and morphological data. New CytB sequences were obtained from GenBank and others were generated herein, including individuals from the previously unanalyzed states of Colima, Morelos, and Veracruz, and the previously unsampled subspecies B. m. brunneus. The mitochondrial $C y t B$ gene was chosen because of its availability and its proven utility to clarify phylogenetic relationships in other Neotominae rodents (Edwards and Bradley 2002; Arellano et al. 2005; Bradley et al. 2007; Rogers et al. 2007; Vallejo and González-Cózatl 2012). Although more than 1,700 specimens of $B$. musculus have been analyzed in previous morphological studies (Osgood 1909; Hooper 1952; Packard 1960), and it was validated that differences in size and coloration among the eight subspecies exist, none of these morphological studies specifically attempted to detect morphometric evidence to confirm or reject the hypothesis of two genetic clades (Amman and Bradley 2004).

\section{Materials and Methods}

DNA sequence data. Mitochondrial sequences of the complete $C y t B$ gene $(1,143$ base pairs) were obtained from five specimens (four $B$. musculus and one $B$. taylori) housed in the mammal collection of the Museo de Zoología, Facultad de Ciencias, Universidad Nacional Autónoma de México, Ciudad de México, México (MZFC). A Qiagen DNEasy Blood \& Tissue kit (Qiagen, Germantown, Maryland) was used to extract whole genomic DNA following the manufacturer's recommended protocols. Polymerase chain reaction (PCR) was used to amplify this gene using the primers MVZ05 (Smith and Patton 1993) and H15915 (Irwin et al. 1991). Each PCR had a final reaction volume of $13 \mu \mathrm{L}$ and contained $6.25 \mu \mathrm{L}$ of GoTaq Green Master Mix (Promega, Madison, WI, U.S.A.), $4.75 \mu \mathrm{L}$ of $\mathrm{H}_{2} 0,0.5 \mu \mathrm{L}$ of each primer $(10 \mu \mathrm{M})$, and $1 \mu \mathrm{L}$ of DNA stock. The PCR thermal profile included 2 minutes of initial denaturation at $95^{\circ} \mathrm{C}$, followed by 38 cycles of 30 seconds of denaturation at $95^{\circ} \mathrm{C}, 30$ seconds of annealing at $50^{\circ} \mathrm{C}$, and 68 seconds for extension at $72^{\circ} \mathrm{C}$. We included a 5-minute final extension step at $72{ }^{\circ} \mathrm{C}$. PCR products $(3 \mu \mathrm{L})$ were visualized using electrophoresis in $1 \%$ agarose gels stained with SYBR Safe DNA Gel Stain (Life Technologies, Carlsbad, CA, U.S.A.). Each PCR product was purified with $1 \mu \mathrm{L}$ of a $20 \%$ dilution of ExoSAP-IT (GE Healthcare Bio-Sciences Corp. Piscataway, NJ, U.S.A.), then incubated for 30 minutes at $37^{\circ} \mathrm{C}$ followed by 15 minutes at $80^{\circ} \mathrm{C}$. Samples were cyclesequenced using $6.1 \mu \mathrm{L}$ of $\mathrm{H}_{2} 0,1.5 \mu \mathrm{L}$ of $5 x$ buffer, $1 \mu \mathrm{L}$ of $10 \mu \mathrm{M}$ primer, $0.4 \mu \mathrm{L}$ of ABI PRISM Big Dye v. 3.1 (Applied Biosystems, Foster City, CA, U.S.A.), and $1 \mu \mathrm{L}$ of the purified template. The cycle-sequencing profile included 1 minute of initial denaturation at $96^{\circ} \mathrm{C}$, followed by 25 cycles of 10 seconds for denaturation at $96^{\circ} \mathrm{C}, 5$ seconds for annealing at $50{ }^{\circ} \mathrm{C}$, and 4 minutes for extension at $60^{\circ} \mathrm{C}$. Cycle sequencing products were purified using an EtOH-EDTA precipitation protocol and were read with an $A B I 3130 x l$ genetic analyzer (Applied Biosystems, Foster City, CA, U.S.A.). DNA sequences were edited, aligned, and visually inspected using MEGA X (Kumar et al. 2018) and FINCHTV 1.4 (Patterson et al. 2004). Nineteen additional CytB sequences of $B$. musculus were recovered from GenBank (Amman and Bradley 2004; Miller and Engstrom 2008; Light et al. 2016), so in total we analyzed 23 individuals of $B$. musculus (representating five subspecies: B. m. brunneus, B. m. infernatis, B. m. musculus, $B$. m. nigriscens, and B. m. pallidus; Figure 1 ) and one B. taylori individual was used as the outgroup (Appendix I). With this new sampling, we almost doubled the genetic samples analyzed by Amman and Bradley (2004), including samples from new localities, states, and subspecies previously not analyzed (Figure 1).

Maximum likelihood (ML) and Bayesian inference (BI) were used to estimate phylogenetic relationships of $B$. musculus. Prior to phylogenetic analyses, the best model and partition scheme (maximally divided by codon position) among all available models in MrBAYEs 3.2 (Ronquist et al. 2012) was selected based on the Bayesian Information Criterion (BIC) in PartitionFinder 2 (Lanfear et al. 2016). The IQ-TREE 1.6.12 (Nguyen et al. 2015) was used to estimate the ML gene tree, with branch support estimated by 1,000 replicates of nonparametric bootstrap. In MRBAYES 3.2, three hot chains and one cold chain were used in two independent runs of 10 million generations, sampling data every 1,000 iterations. Convergence of MCMC results was determined by examining trace plots and sample sizes in Tracer 1.7 (Rambaut et al. 2018). The final topology was obtained using a majority rule consensus tree and considering a burn-in of $25 \%$ (with effective sample sizes $>200$ ). To evaluate levels of genetic differentiation, $p$-distances were estimated in Mega $X$ using the pairwise deletion option and the Kimura 2-parameter model (Kimura 1980). These setting were chosen to facilitate comparison with previous works (Bradley and Baker 2001; Baker and Bradley 2006). 
Morphological analyses. Following the removal of subadult and damaged specimens, morphometric variation was analyzed in 47 specimens of $B$. musculus from three subspecies (B. m. brunneus, B. m. musculus, B. m. pallidus; Figure 1; Appendix II). Twelve cranial measurements as defined by Ávila-Valle et al. (2012) and Hurtado and Pacheco (2017) were obtained using a digital caliper $(0.01 \mathrm{~mm}$ resolution) as follows: condyle-incisive length (CIL), braincase depth $(B C D)$, braincase breadth (BCB), zygomatic breadth (ZB), interorbital constriction (IOC), rostral breadth (BR), maxillary toothrow length (MTL), breadth across M3-M3 (BMM), breadth of M1 (BM1), length of auditory bulla (LAB), dentary greatest length $(\mathrm{DGL})$, and dentary height $(\mathrm{DH})$. Age classes were assigned to the specimens following tooth eruption and wear patterns, and we only analyzed adult specimens. To determine if the molecular results were congruent with the morphological data, we specifically tested for morphological differences between the clades detected in the molecular analyses. Because we were interested in recognizing measurements useful to detect groups within B. musuculus, and sexual size dimorphism has not been supported in this species (Packard 1960; Abuzeineh 2006), females and males were analyzed together.
All univariate analyses and summary statistics were performed in R 3.6.2 (R Core Team 2014). QQ-plots and the Shapiro-Wilk test were used to analyze the normality of the data in each group (clades I and II) and the Levene test from the CAR 3.0-6 package (Fox and Weisberg 2019) to test for homogeneity of variances between groups. All variables fulfilled the normality assumption, and all variables except for IOC and MTL fulfilled the assumption of homogeneity of variance. A Student's t-test was used to determine whether the two clades differed in each of the morphological measurements, using the Welch approximation to degrees of freedom to account for the heteroscedasticity for IOC and MTL (using var.equal = FALSE in the t.test function of R). A significance threshold (a) of 0.05 was implemented. Boxplots were plotted in ggplot2 (Wickham 2011) to better visualize the results.

\section{Results}

DNA sequence data. The final alignment included 207 variable characters, 92 singleton sites, and 115 parsimony informative characters. The best evolutionary model schemes were $\mathrm{K} 80+\mathrm{l}, \mathrm{F} 81+\mathrm{l}$, and $\mathrm{GTR}+\mathrm{G}$ applied to the first, second,

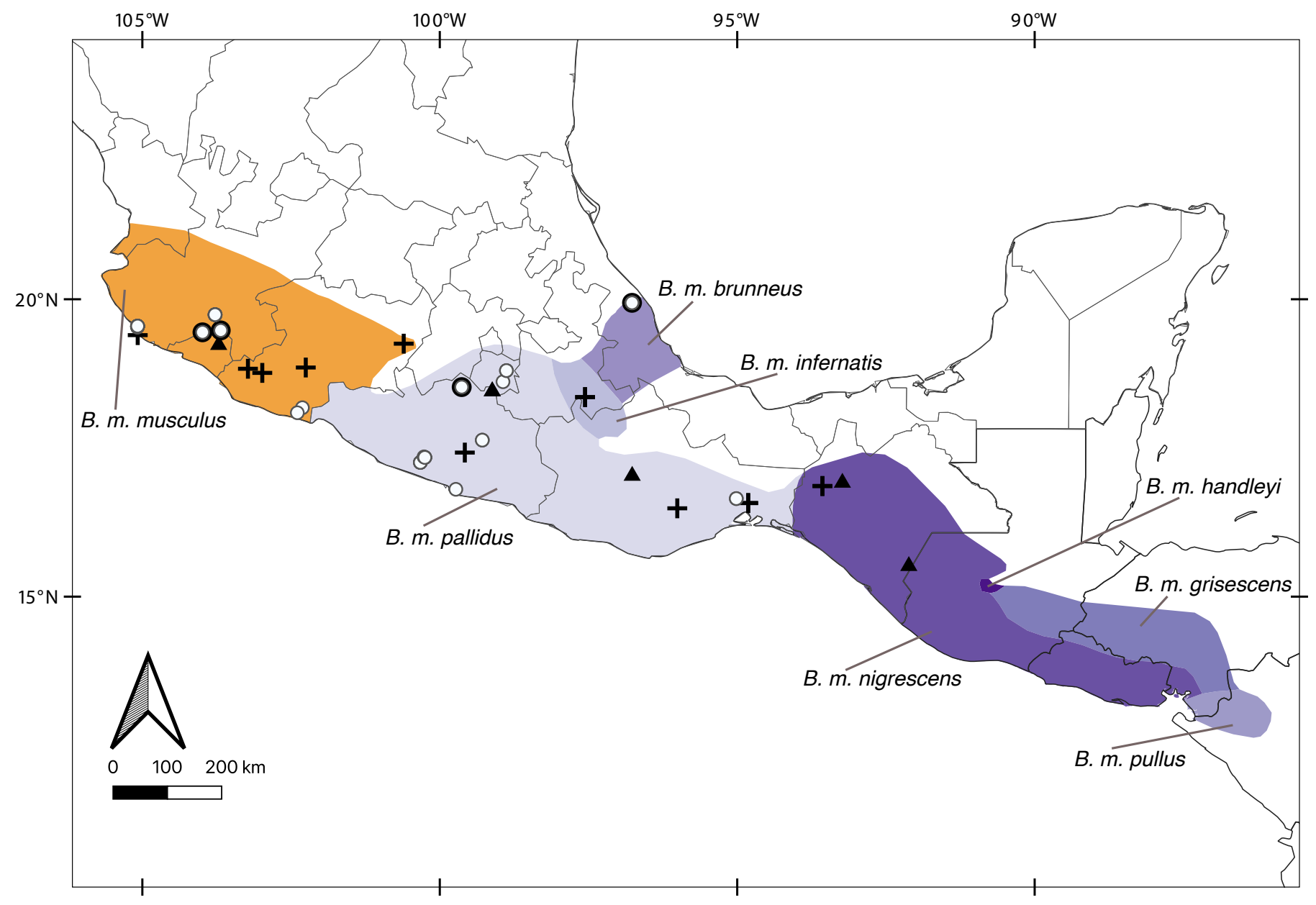

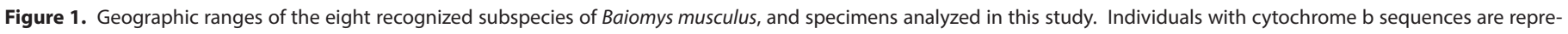

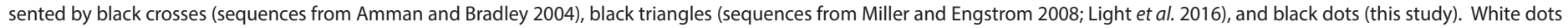
represent individuals with morphological data (this study). 
and third codon positions, respectively. Topologies from $\mathrm{ML}$ and $\mathrm{BI}$ trees were almost identical, but nodal support values were higher in BI (Figure 2). As previously reported, two well-supported clades were recovered within B. musculus (Amman and Bradley 2004). These clades were geographically structured, with clade I including samples from western México (Colima, Jalisco and Michoacán), and clade II including the rest of the samples. Clade II contained two sub-clades, one from central México (Guerrero, Morelos, and Puebla; clade II.a), and the other from eastern México (Chiapas, Oaxaca, and Veracruz; clade II.b). The K2P genetic distances between $B$. taylori and the two clades within $B$. musculus were $>11 \%$, the distance between clades I and II was $6.69 \%$, and between clades II.a and II.b was $3.98 \%$.

Morphological analyses. Based on molecular results, individuals were assigned to two a priori groups: clade I (Colima, Jalisco, and Michoacán; $n=26,1$ of them sequenced) and clade II (Guerrero, Morelos, Oaxaca, and Veracruz; $n=21,2$ of them sequenced; Appendix 2). Although some measurements overlapped between clades, individuals from clade I had significantly larger measurements than clade II in nine morphometric variables (Figure 3 and Table 1; all of the morphometric variables measured, except for BR, BMM, and LAB).

\section{Discussion}

The two mitochondrial lineages within B. musculus previously detected by Amman and Bradley (2004; Figure 2) were recovered, because their clade $C$ is equivalent to our clade $\mathrm{I}$. In addition, the K2P genetic distance between clades I and II was similar to those observed in other recognized sister species in Neotominae, such as in the genus Megadontomys (Vallejo and González-Cózatl 2012), Neotoma (Hernández-Canchola et al. 2021), Peromyscus (Bradley et al. 2007), among others (Bradley and Baker 2001; Baker and Bradley 2006). These two clades seem to be allopatric, but more thorough sampling is needed to determine if there is a distinct boundary between them. The complex topography between the Sierra Madre del Sur and the Transmexican Volcanic Belt, in addition to the mouth of the Balsas River, could be acting as geographic barriers to gene flow between clades in the southern pygmy mouse (Amman and Bradley 2004; Figure 4), and this limit aligns well with boundaries between other cryptic sister mammal taxa such as the mouse opossums (Arcangeli et al. 2018) and the Osgood's deermice (Ruiz-Vega et al. 2018). Additionally, multiple diversification events in western México generated many Mexican endemic mammal species, including

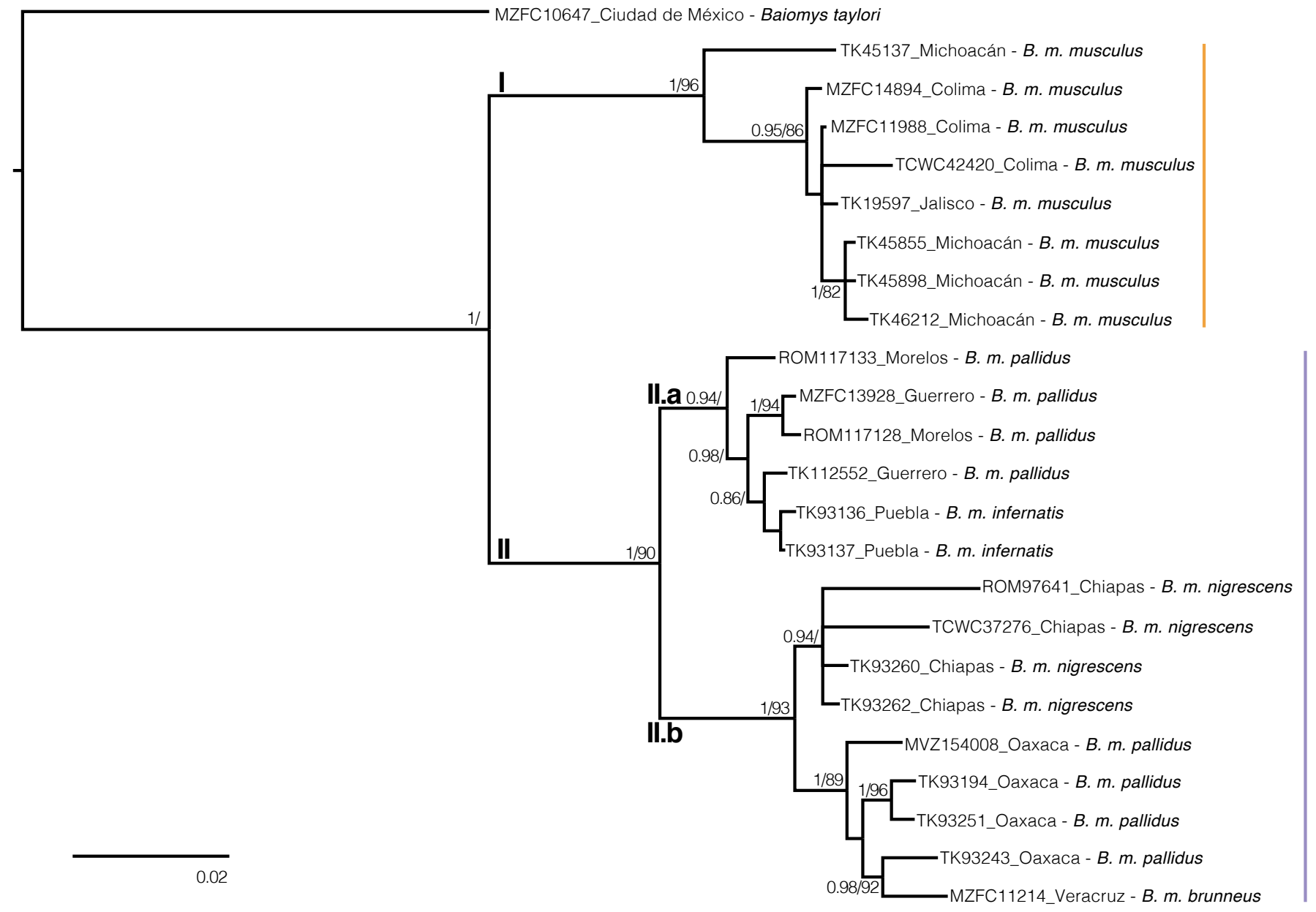

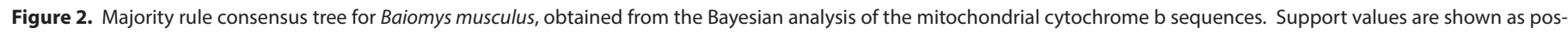

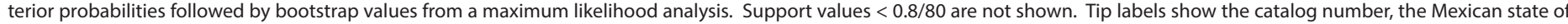
each sample and the taxa of each tip. Clade I is in orange and clade II in purple. 
other neotomine rodents (Osgoodomys banderanus, Xenomys nelsoni, Hodomys alleni, and Peromyscus perfulvus), in addition to the pygmy spotted skunk (Spilogale pygmaea), two species of mouse opossums (Tlacuatzin), the Mexican shrew (Megasorex gigas), and the banana bat (Musonycteris harrisoni), among others (Ceballos 2014; Arcangeli et al. 2018). This evidence suggests that the evolutionary history of clades I and II within B. musculus could have been influenced by the complex topography of western México, as in many other mammal taxa.

Baiomys musculus from clade I are distributed in Colima, Jalisco, and Michoacán, and specimens from these Mexican states were the largest individuals examined. Although the sample size was relatively small, our results are consistent with previous morphological evaluations that analyzed larger numbers of specimens from Guatemala and México ( $n=299$, Osgood 1909), México ( $n=351$, Hooper 1952), and from El Salvador, Guatemala, Honduras, México, and Nicaragua ( $n=1,748$; Packard 1960). In these previous morphological reviews, individuals from western México (Nayarit, Jalisco, Colima, and Michoacán) were larger in external and cranial dimensions than other Mexican and Central American specimens. This morphological differentiation of the populations from western México has been recognized for many years, as evidenced by their recognition as the subspecies B. m. musculus (Osgood 1909; Hooper 1952; Packard 1960; Figure 1).

Packard (1960) also noted increasing size in B. musculus from south to north. This general trend follows Bergmann's rule. However, B. m. musculus is the most distinct subspecies of the southern pygmy mouse, and it was proposed that its difference could be related to character displacement (Packard 1960) that could magnify the Bergmann's rule, because in western México $B$. musculus and $B$. taylori
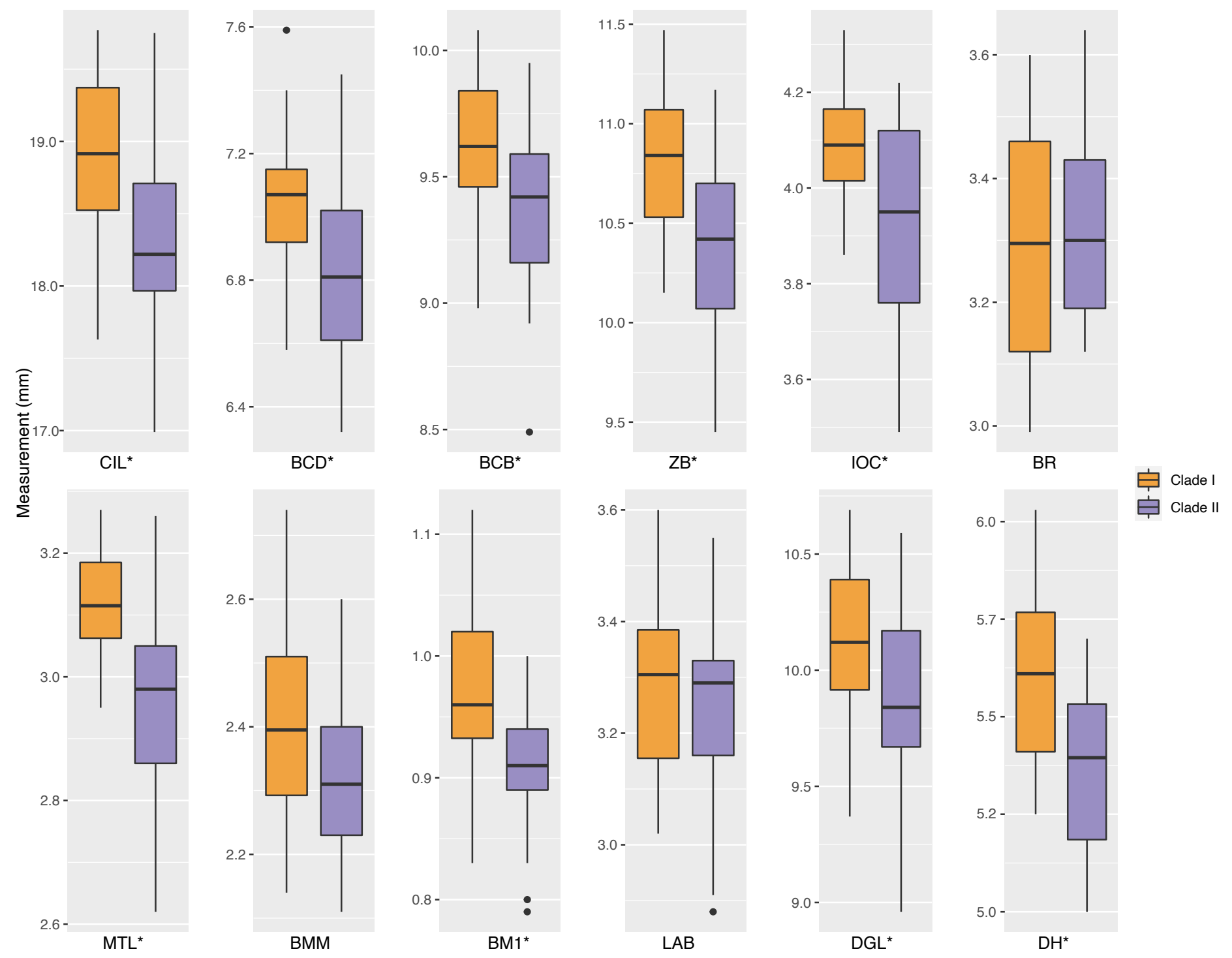

Figure 3. Boxplots summarizing the cranial and mandibular measurements of Baiomys musculus. Each plot represents a morphometric variable: condyle-incisive length (CIL), braincase depth (BCD), braincase breadth (BCB), zygomatic breadth (ZB), interorbital constriction (IOC), rostral breadth (BR), maxillary toothrow length (MTL), breadth across M3-M3 (BMM), breadth of $\mathrm{M} 1(\mathrm{BM} 1)$, length of auditory bulla ( $\mathrm{LAB})$, dentary greatest length $(\mathrm{DGL})$, and dentary height $(\mathrm{DH})$. $P$-values that were significant different $(<0.05)$ between clades are shown with an asterisk. Horizontal lines represent medians, boxes span the interval between the $25^{\text {th }}$ and $75^{\text {th }}$ percentiles, and the range of the vertical lines show the minimum and maximum values for each variable. Black dots show measurements that are farther from the mean than 1.5 times the interquartile range. 
Table 1. Summary statistics and test statistics of morphological variables measured in $B$. musculus (condyle-incisive length, $\mathrm{CIL}$; braincase depth, $\mathrm{BCD}$; braincase breadth, $\mathrm{BCB}$; zygomatic breadth, ZB; interorbital constriction, IOC; rostral breadth, BR; maxillary toothrow length, MTL; breadth across M3-M3, BMM; breadth of M1, BM1; length of auditory bulla, LAB; dentary greatest length, DGL; and dentary height, $\mathrm{DH}$ ). Mean and standard deviation (sd) are shown for each clade, followed by the Student's t statistic $(t)$, degrees of freedom (df; estimated using the Welch approximation for IOC and MTL to account for heteroscedasticity), and the $P$-value $(P)$. $P$-values that were significant $(<0.05)$ are shown in bold type.

\section{Clade I}

Clade II

\begin{tabular}{lrlrllll} 
& Mean & sd & Mean & sd & \multicolumn{1}{l}{ df } & \multicolumn{1}{c}{$\boldsymbol{P}$} \\
\hline CIL & 18.90 & 0.576 & 18.30 & 0.687 & 3.20 & 44.0 & 0.003 \\
BCD & 7.05 & 0.229 & 6.83 & 0.293 & 2.84 & 45.0 & $\mathbf{0 . 0 0 7}$ \\
BCB & 9.65 & 0.265 & 9.36 & 0.344 & 3.20 & 44.0 & $\mathbf{0 . 0 0 3}$ \\
ZB & 10.80 & 0.361 & 10.40 & 0.480 & 3.32 & 44.0 & $\mathbf{0 . 0 0 2}$ \\
IOC & 4.09 & 0.116 & 3.95 & 0.219 & 2.76 & 28.9 & $\mathbf{0 . 0 1 0}$ \\
BR & 3.30 & 0.185 & 3.32 & 0.163 & -0.35 & 45.0 & 0.729 \\
MTL & 3.12 & 0.088 & 2.97 & 0.155 & 3.92 & 30.2 & $<\mathbf{0 . 0 0 1}$ \\
BMM & 2.40 & 0.152 & 2.32 & 0.128 & 1.86 & 45.0 & 0.070 \\
BM1 & 0.98 & 0.072 & 0.91 & 0.056 & 3.84 & 45.0 & $<\mathbf{0 . 0 0 1}$ \\
LAB & 3.28 & 0.169 & 3.23 & 0.175 & 0.92 & 45.0 & 0.365 \\
DGL & 10.10 & 0.358 & 9.85 & 0.445 & 2.25 & 42.0 & 0.030 \\
DH & 5.60 & 0.226 & 5.37 & 0.217 & 3.33 & 40.0 & $\mathbf{0 . 0 0 2}$ \\
\hline
\end{tabular}

are sympatric and they are more morphologically distinct than where they are allopatric (Hooper 1952; Packard 1960). Analyses of cranial geometric morphometrics rejected the character displacement hypothesis between B. musculus and B. taylori (Abuzeineh 2006), but this proposal has not been tested in postcranial structures, or with other methodologies, and deserves attention to understand the processes that originated sympatric populations of $B$. musculus clade I / B. taylori, and the allopatric populations of B. musculus clade II / B. taylori. Martínez-Gordillo et al. (2010) tested whether clades I and II had different ecological niches, and although clade I inhabits warmer and drier environments than clade II, the ecological models showed nesting of the niches of the two clades (ecological niche modeling of clade I recovered most of the distribution of clade II, and vice-versa). Interestingly, $B$. taylori, which inhabits from the United States of America to central México, also has two detected clades with a lower genetic divergence than $B$. musculus (2.82 \%; Amman and Bradley 2004), but the ecological niches were different between the two (MartínezGordillo et al. 2010). These contrasting genetic and environmental results between the northern and southern pygmy mice could suggest that different evolutionary processes are acting in each taxon within Baiomys.

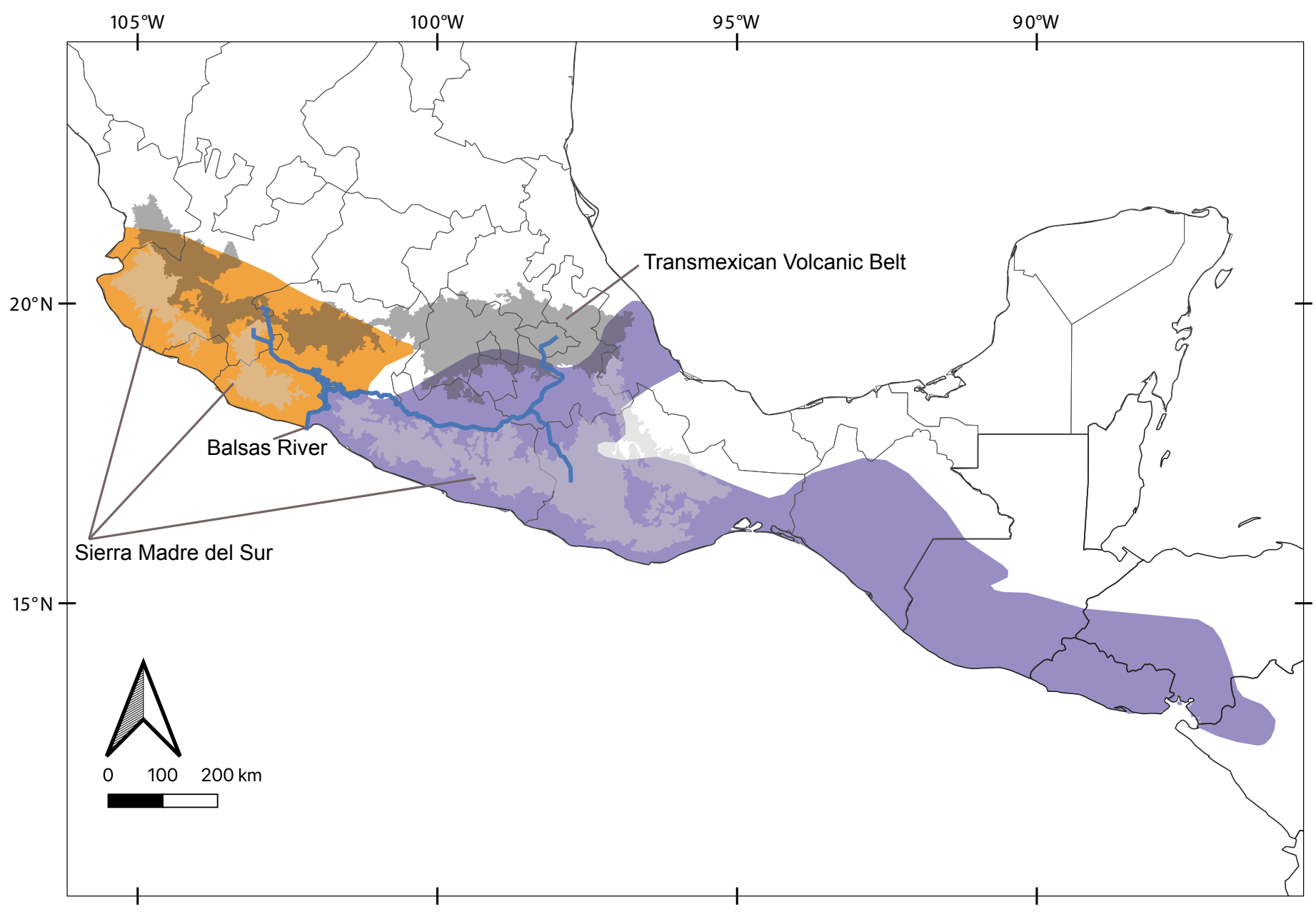

Figure 4. Revisited geographic ranges in the southern pigmy mice. Map colors show the preliminary suggested geographic ranges within Baiomys musculus of clade I (orange) and B. brunneus clade II (purple). The main biogeographic barriers discussed in this work also are shown. 
In addition to the high levels of mitochondrial divergence (Amman and Bradley 2004) and morphological differences (external size, coat color, and certain cranial measurements; see Packard 1960 for more details) between $B$. $m$. musculus and the remaining subspecies, a substantial subdivision between $B$. musculus samples from Jalisco and Colima $(n=9)$ versus Chiapas, Oaxaca, and Veracruz $(n=11)$ was reported using allozymes (Calhoun et al. 1989). In the present work, more than using our limited sampling to draw conclusions about the taxonomic status of B. m. musculus (Figures 2, 3, Table 1), we aim to integrate the multiple and impressive reviews that have analyzed the variation within B. musculus (Osgood 1909; Hooper 1952; Packard 1960; Calhoun et al. 1989; Amman and Bradley 2004).

Considering all of these data, collected independently over more than a century, it appears that clade I, the Mexican endemic pygmy mice that inhabits in Colima, Jalisco, Michoacán, and Nayarit, could be named as B. musculus (Merriam 1892), and that all other populations of the southern pygmy mouse (including the brunneus, grisescens, handleyi, infernatis, nigrescens, pallidus, and pullus populations) seem to merit specific status and, following taxonomic priority, could be referred to as B. brunneus (Allen and Chapman, 1897). However, studies of additional data sets, such as nuclear / genomic data or Central American populations, will be required to definitively confirm the taxonomic status of these specimens. The substructure detected within clade II (Figure 2) also deserves additional attention: clade II.a appears to be restricted to the Balsas Basin and clade II.b to southeastern México. This phylogeographic pattern also has been reported in other mammal species, such as the Mesoamerican yellowshouldered bat (Hernández-Canchola and León-Paniagua 2017) and the nine-banded armadillo (Arteaga et al. 2012) and this genetic differentiation does not agree with the geographic boundaries between subspecies of $B$. musculus (Figures 1,2), so future studies will be needed to verify their validity. Basic aspects of the neotomine rodents, such as the number of species that inhabit North and Central America, are still not clear (Miller and Engstrom 2008; Platt et al. 2015; Sullivan et al. 2017). This knowledge gap will likely continue to exist in taxa that are rare and/ or have restricted distributions (Gardner and Carleton 2009; Fernández 2014), unless the use of Next Generation Sequencing methods allow DNA data to be obtained from ancient specimens hosted in mammal collections (Castañeda-Rico et al. 2020). However, in more common and abundant species, as $B$. musculus, it will be easier to obtain and analyze data to solve these taxonomic uncertainties, which will allow us to understand the processes that generate and maintain biodiversity (Upham et al. 2019).

\section{Acknowledgments}

Livia León Paniagua thanks Dr. David J. Schmidly, whose support was invaluable. He gave us the opportunity to accompany him on one of his field trips to México, provided our first Sherman traps and some nets, and suggested topics for our Bachelor thesis work. Our special thanks also to L. Bradley and R. Bradley for inviting us to participate in this volume. We thank the Posgrado en Ciencias Biológicas Universidad Nacional Autónoma de México for its support in conducting this research. Funding was provided by the U.S. National Science Foundation (NSF DEB-1754393 and DEB-1441634), and the Mexican National Council for Science and Technology (CONACyT CVU-549963).

\section{Literature Cited}

Abuzeineh, A. A. 2006. Baiomys (Mammalia: Rodentia): geographic variation, secondary sexual dimorphism, and character displacement in sister species. Master Thesis, Texas Tech University, Lubock, U.S.A

Allen, J. A., And F. M. Chapman. 1897. On a collection of mammals from Jalapa and Las Vigas, State of Veracruz, Mexico. Bulletin of the American Museum of Natural History 9:197-208.

Amman, B. R., AND R. D. Bradley. 2004. Molecular evolution in Baiomys (Rodentia: Sigmodontinae): evidence for a genetic subdivision in B. musculus. Journal of Mammalogy 85:162-166.

Arcangel, J., J. E. Light, and F. A. Cervantes. 2018. Molecular and morphological evidence of the diversification in the gray mouse opossum, Tlacuatzin canescens (Didelphimorphia), with description of a new species. Journal of Mammalogy 99:138-158.

Arellano, E., F. X. González-Cozátl, and D. S. Rogers. 2005. Molecular systematics of Middle American harvest mice Reithrodontomys (Muridae), estimated from mitochondrial cytochrome $b$ gene sequences. Molecular Phylogenetics and Evolution 37:529-540.

Arteaga, M. C., D. Piñero, L. E. Eguiarte, J. Gasca, and R. A. MedelLín. 2012. Genetic structure and diversity of the nine-banded armadillo in Mexico. Journal of Mammalogy 93:547-559.

Ávila-Valle, Z. A., A. Castro-Campillo, L. León-Paniagua, I. H. Salgado-Ugalde, A. G. Navarro-Sigüenza, B. E. Hernández-BaNos, AND J. Ramírez-Pulido. 2012. Geographic variation and molecular evidence of the blackish deer mouse complex (Peromyscus furvus, Rodentia: Muridae). Mammalian Biology 77:166-177.

Baker, R. J., AND R. D. Bradley. 2006. Speciation in mammals and the genetic species concept. Journal of Mammalogy 87:643-662.

Bradley, R. D., AND R. J. Baker. 2001. A test of the genetic species concept: cytochrome-b sequences and mammals. Journal of Mammalogy 82:960-973.

Bradley, R. D., N. D. Durish, D. S. Rogers, J. R. Miller, M. D. EngSTROM, AND C. W. KILPATRICK. 2007. Toward a molecular phylogeny for Peromyscus: evidence from mitochondrial cytochrome- b sequences. Journal of Mammalogy 88:1146-1159.

Calmoun, S. W., M. D. Engstrom, and I. F. Greenbaum. 1989. Biochemical variation in pygmy mice (Baiomys). Journal of Mammalogy 70:374-381.

Castañeda-Rico, S., L. León-Paniagua, C. W. Edwards, and J. E. Maldonado. 2020. Ancient DNA from museum specimens and Next Generation Sequencing help resolve the controversial evolutionary history of the critically endangered Puebla deer mouse. Frontiers in Ecology and Evolution 8:94. 
Ceballos, G. 2014. Mammals of Mexico. Johns Hopkins University Press, Baltimore, Maryland. U.S.A.

Edwards, C. W., ANd R. D. Bradley. 2002. Molecular systematics of the genus Neotoma. Molecular Phylogenetics and Evolution 25:489-500.

Fernández, J. A. 2014. Mitochondrial phylogenetics of a rare Mexican endemic: Nelson's woodrat, Neotoma nelsoni (Rodentia: Cricetidae), with comments on its biogeographic history. The Southwestern Naturalist 59:81-90.

Fox, J., AND S. Weisberg. 2019. An R companion to applied regression. Sage, Thousand Oaks, California, U.S.A.

Galván-Ramírez, M. A. 2020. Estructura de la comunidad de roedores silvestres asociados a jales de Huautla, Morelos. Master Thesis, Universidad Autónoma del Estado de Morelos, Cuernavaca, México.

García-Estrada, C., M. de L. Romero-Almaraz, and C. SánchezHernández. 2002. Comparison of rodent communities in sites with different degrees of disturbance in deciduous forest of southeastern Morelos, México. Acta Zoológica Mexicana 85:153-168.

Gardner, A. L., and M. D. Carleton. 2009. A new species of Reithrodontomys, subgenus Aporodon (Cricetidae: Neotominae), from the highlands of Costa Rica, with comments on Costa Rican and Panamanian Reithrodontomys. Bulletin of the American Museum of Natural History 331:157-182.

Goldman, E. A. 1932. Two new mammals from Honduras. Proceedings of the Biological Society of Washington 45:121-124.

Hernández-Canchola, G., and L. León-Paniagua. 2017. Genetic and ecological processes promoting early diversification in the lowland Mesoamerican bat Sturnira parvidens (Chiroptera: Phyllostomidae). Molecular Phylogenetics and Evolution 114:334-345.

Hernández-Canchola, G., L. León-Paniagua, and J. A. Esselstyn. 2021. Mitochondrial DNA indicates paraphyletic relationships of disjunct populations in the Neotoma mexicana species group. Therya 12: On line. https://www.revistas-conacyt. unam.mx/therya/index.php/THERYA/article/view/1082

Hooper, E. T. 1952. Notes on the pygmy mouse (Baiomys), with description of a new subspecies from Mexico. Journal of Mammalogy 33:90-97.

Hurtado, N., ANd V. Pacheco. 2017. Revision of Neacomys spinosus (Thomas, 1882) (Rodentia: Cricetidae) with emphasis on Peruvian populations and the description of a new species. Zootaxa 4242:401-440.

Irwin, D. M., T. D. Kocher, AND A. C. Wilson. 1991. Evolution of the cytochrome $b$ gene of mammals. Journal of Molecular Evolution 32:128-144.

Kimura, M. 1980. A simple method for estimating evolutionary rates of base substitutions through comparative studies of nucleotide sequences. Journal of Molecular Evolution 16:111-120.

Kumar, S., G. Stecher, M. Lı, C. Knyaz, and K. Tamura. 2018. MEGA X: molecular evolutionary genetics analysis across computing platforms. Molecular Biology and Evolution 35:1547-1549.

Lanfear, R., P. B. Frandsen, A. M. Wright, T. Senfeld, and B. CalCOTT. 2016. PartitionFinder 2: new methods for selecting partitioned models of evolution for molecular and morphologi- cal phylogenetic analyses. Molecular Biology and Evolution 34:772-773.

Lee, M. R., AND F. F. B. Elder. 1977. Karyotypes of eight species of Mexican rodents (Muridae). Journal of Mammalogy 58:479-487.

Light, J. E., M. O. Ostroff, And D. J. Hafner. 2016. Phylogeographic assessment of the northern pygmy mouse, Baiomys taylori. Journal of Mammalogy 97:1081-1094.

Martínez-Gordillo, D., O. Rojas-Soto, And A. Espinosa de los MonTEROS. 2010. Ecological niche modelling as an exploratory tool for identifying species limits: an example based on Mexican muroid rodents. Journal of Evolutionary Biology 23:259-270.

Mearns, E. A. 1907. Mammals of the Mexican boundary of the United States part I, families Didelphidae to Muridae. Bulletin of the United States National Museum 56:1-530.

Merriam, C. H. 1892. Descriptions of nine new mammals collected by E. W. Nelson in the states of Colima and Jalisco, Mexico. Proceedings of the Biological Society of Washington 7:164-174.

MilleR, G. S. 1912. List of North American land mammals in the United States National Musuem, 1911. Bulletin of the United States National Museum 79:1-455.

Miller, J. R., AND M. D. Engstrom. 2007. Vocal stereotypy and singing behavior in baiomyine mice. Journal of Mammalogy 88:1447-1465.

Miller, J. R., And M. D. Engstrom. 2008. The relationships of major lineages within peromyscine rodents: a molecular phylogenetic hypothesis and systematic reappraisal. Journal of Mammalogy 89:1279-1295.

Nguyen, L. T., H. A. Schmidt, A. von Haeseler, and B. Q. Minh. 2015. IQ-TREE: a fast and effective stochastic algorithm for estimating maximum-likelihood phylogenies. Molecular $\mathrm{Bi}$ ology and Evolution 32:268-274.

Osgood, W. H. 1904. Thirty new mice of the genus Peromyscus from Mexico and Guatemala. Proceedings of the Biological Society of Washington 17:55-77.

Osgood, W. H. 1909. Revision of the mice of the American genus Peromyscus. North American Fauna 28:1-285.

Packard, R. L. 1958. New subspecies of the rodent Baiomys from Central America. University of Kansas Publications, Museum of Natural History 9:397-404.

PACKARD, R. L. 1960. Speciation and evolution of the pygmy mice, genus Baiomys. University of Kansas Publications, Museum of Natural History 9:579-670.

Packard, R. L., ANd J. B. Montgomery. 1978. Baiomys musculus. Mammalian Species 102:1-3.

Pardiñas, U., P. Myers, L. León-Paniagua, N. Ordoñez-Garza, J. Cook, B. Krystufek, R. Haslauer, R. D. Bradley, G. Shembrot, And J. Patton. 2017. Family Cricetidae (true hamsters, voles, lemmings and new world rats and mice). Pp. 204-279, in Handbook of the Mammals of the World. Volume 7 Rodents II (Wilson, D. E., R. A. Mittermeier, and T. E. Lacher, eds.). Lynx Edicions. Barcelona, Spain.

Patterson, J., B. Chamberlain, and D. Thayer. 2004. Finch TV Version 1.4.0. Published by authors.

Platt, R. N., B. R. Amman, M. S. Keith, C. W. Thompson, and R. D. Bradley. 2015. What is Peromyscus? Evidence from nuclear and mitochondrial DNA sequences suggests the need for a new classification. Journal of Mammalogy 96:708-719. 
R Core Team. 2014. R: a language and environment for statistical computing. R Foundation for Statistical Computing, Vienna, Austria. URL https://www.R-project.org/.

Rambaut, A., A. J. Drummond, D. Xie, G. Baele, and M. A. Suchard. 2018. Posterior summarization in bayesian phylogenetics using Tracer 1.7. Systematic Biology 67:901-904.

Rogers, D. S., C. C. Funk, J. R. Miller, And M. D. Engstrom. 2007. Molecular phylogenetic relationships among crested-tailed mice (genus Habromys). Journal of Mammalian Evolution 14:37-55.

Ronquist, F., M. Teslenko, P. Van Der Mark, D. L. Ayres, A. Darling, S. Höhna, B. Larget, L. Liu, M. A. Suchard, and J. P. Huelsenbeck. 2012. Mrbayes 3.2: efficient bayesian phylogenetic inference and model choice across a large model space. Systematic Biology 61:539-542.

Ruiz-Vega, M. L., G. Hernández-Canchola, and L. León-Paniagua. 2018. Molecular systematics and phylogeography of the endemic Osgood's deermouse Osgoodomys banderanus (Rodentia: Cricetidae) in the lowlands of western Mexico. Molecular Phylogenetics and Evolution 127:867-877.

Russell, R. J. 1952. A new subspecies of pygmy mouse, Baiomys musculus, from Morelos, Mexico. Proceedings of the Biological Society of Washington 65:21-22.

Schnell, G. D., C. J. Poindexter, C. Sánche-Hernández, M.de L. Romero-Alamaráz, M. L. Kennedy, T. L. Best, M. C. Wooten, and A. Pérez-Jiménez. 2008. Demographic features and habitat preferences of southern pygmy mice (Baiomys musculus) in Colima, Mexico. Canadian Journal of Zoology 86:507-524.

Smith, M. F., AND J. L. Patton. 1993. The diversification of South American murid rodents: evidence from mitochondrial DNA sequence data for the akodontine tribe. Biological Journal of the Linnean Society 50:149-177.

Sullivan, K. A. M., R. N. Platt, R. D. Bradley, and D. A. Ray. 2017. Whole mitochondrial genomes provide increased resolution and indicate paraphyly in deer mice. BMC Zoology 2:1-6.

True, F. W. 1894. On the relationships of Taylor's mouse, Sitomys taylori. Proceedings of the United States National Museum 16:757-758.

Upham, N. S., J. A. Esselstyn, and W. Jetz. 2019. Inferring the mammal tree: species-level sets of phylogenies for questions in ecology, evolution, and conservation. PLoS Biology 17:e3000494.

Vallejo, R. M., and F. X. González-Cózatl. 2012. Phylogenetic affinities and species limits within the genus Megadontomys (Rodentia: Cricetidae) based on mitochondrial sequence data. Journal of Zoological Systematics and Evolutionary Research 50:67-75.

Vargas, V., D. Valenzuela-Galván, and R. E. Alcalá. 2012. Is genetic structure of the southern pygmy mouse Baiomys musculus (Cricetidae) related to human-induced spatial landscape heterogeneity in a tropical dry forest? Genetica 140:287-295.

Wıскнам, H. 2011. ggplot2. Wiley Interdisciplinary Reviews: Computational Statistics 3:180-185. 
Appendix 1

Specimens with the mitochondrial cytochrome b analyzed in this work.

\begin{tabular}{|c|c|c|c|c|c|c|}
\hline Taxa & Mexican state & Lat & Long & Catalog \# & Tissue \# & Genbank \\
\hline B. taylori & Ciudad de México & 19.325 & -98.986 & MZFC 10647 & 5043 & MZ056876 \\
\hline B. musculus & Colima & 19.478 & -103.683 & MZFC 11988 & 4439 & MZ056877 \\
\hline B. musculus & Colima & 19.445 & -103.989 & MZFC 14894 & 6295 & MZ056878 \\
\hline B. musculus & Colima & 19.233 & -103.717 & TCWC 42420 & & MZ056878 \\
\hline B. musculus & Jalisco & 19.398 & -104.962 & TTU 37737 & TK19597 & AF548478 \\
\hline B. musculus & Michoacán & 19.254 & -100.491 & & TK45137 & AF548484 \\
\hline B. musculus & Michoacán & 18.763 & -102.868 & & TK45855 & AF548483 \\
\hline B. musculus & Michoacán & 18.833 & -103.109 & & TK45898 & AF548485 \\
\hline B. musculus & Michoacán & 18.854 & -102.137 & & TK46212 & AF548482 \\
\hline B.b.brunneus & Veracruz & 19.941 & -96.769 & MZFC 11214 & 3281 & MZ056880 \\
\hline B.b. infernatis & Puebla & 18.356 & -97.442 & TTU 82658 & TK93136 & AF548488 \\
\hline B.b. infernatis & Puebla & 18.356 & -97.442 & TTU 82659 & TK93137 & AF548489 \\
\hline B. b. nigrescens & Chiapas & 15.517 & -92.117 & ROM 97641 & & EF989933 \\
\hline B. b. nigrescens & Chiapas & 16.917 & -93.233 & TCWC 37276 & & KU298967 \\
\hline B. b. nigrescens & Chiapas & 16.861 & -93.453 & & TK93260 & AF548486 \\
\hline B. b. nigrescens & Chiapas & 16.861 & -93.453 & & TK93262 & AF548487 \\
\hline B.b.pallidus & Guerrero & 18.525 & -99.632 & MZFC 13928 & 3614 & MZ056879 \\
\hline B.b.pallidus & Guerrero & 17.424 & -99.464 & TTU 90341 & TK112552 & AF548490 \\
\hline B. b.pallidus & Morelos & 18.454 & -99.119 & ROM 117128 & & EF989934 \\
\hline B.b.pallidus & Morelos & 18.454 & -99.119 & ROM 117133 & & EF989935 \\
\hline B.b.pallidus & Oaxaca & 17.033 & -96.767 & MVZ 154008 & & KU298966 \\
\hline B.b.pallidus & Oaxaca & 16.486 & -95.893 & & TK93194 & AF548481 \\
\hline B.b.pallidus & Oaxaca & 16.575 & -94.701 & & TK93251 & AF548479 \\
\hline B. b. pallidus & Oaxaca & 16.575 & -94.701 & & TK93253 & AF548480 \\
\hline
\end{tabular}


Appendix 2

Specimens with morphological data analyzed in this work. Specimens that have cytochrome b sequences are showed with an asterisk.

\begin{tabular}{|c|c|c|c|c|c|c|}
\hline Taxa & state & Lat & Long & Sex & Catalog \# & Field \# \\
\hline B. musculus & Colima & 19.446 & -103.989 & Female & MZFC 14896 & MLR160 \\
\hline B. musculus* & Colima & 19.478 & -103.683 & Male & MZFC 11988 & MYACH430 \\
\hline B. musculus & Jalisco & 19.531 & -105.083 & Female & MZFC 9818 & MCHA001 \\
\hline B. musculus & Jalisco & 19.742 & -103.778 & Male & MZFC 10458 & FCR074 \\
\hline B. musculus & Jalisco & 19.742 & -103.778 & Female & MZFC 10459 & FCR075 \\
\hline B. musculus & Jalisco & 19.742 & -103.778 & Female & MZFC 10460 & FCR076 \\
\hline B. musculus & Jalisco & 19.548 & -105.082 & Male & MZFC 10685 & CHAM036 \\
\hline B. musculus & Jalisco & 19.548 & -105.082 & Male & MZFC 10686 & CHAM060 \\
\hline B. musculus & Jalisco & 19.546 & -105.082 & Female & MZFC 12368 & MCHAM119 \\
\hline B. musculus & Jalisco & 19.546 & -105.082 & Female & MZFC 12369 & MCHAM123 \\
\hline B. musculus & Jalisco & 19.546 & -105.082 & Female & MZFC 12370 & MCHAM126 \\
\hline B. musculus & Jalisco & 19.546 & -105.082 & Female & MZFC 12371 & MCHAM127 \\
\hline B. musculus & Jalisco & 19.546 & -105.082 & Male & MZFC 12373 & MCHAM132 \\
\hline B. musculus & Jalisco & 19.546 & -105.082 & Male & MZFC 12374 & MCHAM133 \\
\hline B. musculus & Jalisco & 19.550 & -105.080 & Male & MZFC 12775 & MCHAM 111 \\
\hline B. musculus & Jalisco & 19.550 & -105.080 & Male & MZFC 12777 & MCHAM 110 \\
\hline B. musculus & Jalisco & 19.550 & -105.080 & Female & MZFC 12778 & MCHAM108 \\
\hline B. musculus & Jalisco & 19.550 & -105.080 & Female & MZFC 12779 & MCHAM107 \\
\hline B. musculus & Jalisco & 19.547 & -105.081 & Male & MZFC 12781 & MCHAM098 \\
\hline B. musculus & Jalisco & 19.550 & -105.080 & Male & MZFC 12783 & MCHAM103 \\
\hline B. musculus & Jalisco & 19.742 & -103.778 & Female & MZFC 12795 & FCR085 \\
\hline B. musculus & Jalisco & 19.742 & -103.778 & Male & MZFC 12798 & FCR092 \\
\hline B. musculus & Jalisco & 19.742 & -103.778 & Female & MZFC 12799 & FCR097 \\
\hline B. musculus & Jalisco & 19.742 & -103.778 & Male & MZFC 13616 & FCR073 \\
\hline B. musculus & Michoacán & 18.178 & -102.310 & Female & MZFC 10196 & MBB108 \\
\hline B. musculus & Michoacán & 18.093 & -102.396 & Female & MZFC 10197 & MBB113 \\
\hline B.b.brunneus & Veracruz & 19.941 & -96.769 & Female & MZFC 11094 & MRM031 \\
\hline B.b.brunneus* & Veracruz & 19.941 & -96.769 & Male & MZFC 11214 & MRM038 \\
\hline B.b.brunneus & Veracruz & 19.941 & -96.769 & Female & MZFC 11219 & MRM032 \\
\hline B.b.pallidus & Guerrero & 16.806 & -99.731 & Male & MZFC 727 & 2205-132МТВ \\
\hline B.b.pallidus & Guerrero & 17.342 & -100.252 & Female & MZFC 2356 & 953JJG \\
\hline B.b.pallidus & Guerrero & 17.258 & -100.327 & Male & MZFC 2357 & 1150JJG \\
\hline B.b.pallidus & Guerrero & 17.342 & -100.252 & Female & MZFC 2358 & $949 J J G$ \\
\hline B.b.pallidus & Guerrero & 17.342 & -100.252 & Male & MZFC 2359 & 957JJG \\
\hline B.b.pallidus & Guerrero & 17.258 & -100.327 & Male & MZFC 2360 & $1105 \mathrm{JJG}$ \\
\hline B.b.pallidus & Guerrero & 17.258 & -100.327 & Female & MZFC 2361 & $1104 \mathrm{JJG}$ \\
\hline B.b.pallidus & Guerrero & 17.258 & -100.327 & Male & MZFC 2362 & $1103 \mathrm{JJG}$ \\
\hline B.b.pallidus & Guerrero & 17.352 & -100.266 & Male & MZFC 2363 & 916JJG \\
\hline B.b.pallidus & Guerrero & 17.342 & -100.252 & Male & MZFC 2364 & 958JJG \\
\hline B. b. pallidus* & Guerrero & 18.525 & -99.632 & Female & MZFC 13928 & GHC035 \\
\hline B.b.pallidus & Guerrero & 17.633 & -99.286 & Male & MZFC 14875 & MLR113 \\
\hline B.b.pallidus & Guerrero & 17.633 & -99.286 & Male & MZFC 14879 & MLR109 \\
\hline B.b.pallidus & Morelos & 18.614 & -98.938 & Female & MZFC 9591 & RAG375 \\
\hline B.b.pallidus & Morelos & 18.802 & -98.880 & Female & MZFC 13918 & GHC076 \\
\hline B.b.pallidus & Morelos & 18.802 & -98.880 & Female & MZFC 13919 & GHC086 \\
\hline B.b.pallidus & Oaxaca & 16.650 & -95.017 & Male & MZFC 10055 & NIZA043 \\
\hline B.b.pallidus & Oaxaca & 16.650 & -95.017 & Male & MZFC 10056 & NIZA044 \\
\hline
\end{tabular}


SYSTEMATICS OF B. MUSCULUS

302 THERYA Vol. 12 (2): 291-301 